\title{
Continental fishes from the Tambaba Environmentally Protected Area, Paraíba State, Brazil
}

\author{
Telton Pedro Anselmo Ramos ${ }^{1}$; Yuri Gomes Ponce de Carvalho-Rocha² ; Leonardo Oliveira-Silva ${ }^{3}$; \\ Sílvia Yasmin Lustosa-Costa ${ }^{4}$ \& Paula Honório Pires Ferreira ${ }^{5}$
}

${ }^{1}$ Universidade Estadual da Paraíba (UEPB), Departamento de Biologia (DEPBIO), Laboratório de Ecologia Aquática. Campina Grande, PB, Brasil. ORCID: http://orcid.org/0000-0002-3808-8701. E-mail: telton@gmail.com

${ }^{2}$ Universidade Federal da Paraíba (UFPB), Centro de Ciências Exatas e da Natureza (CCEN), Departamento de Sistemática e Ecologia (DSE), Laboratório de Sistemática e Morfologia de Peixes. João Pessoa, PB, Brasil. ORCID: http://orcid.org/0000-0003-3123-0581.E-mail:yuri_gpcr@hotmail.com

${ }^{3}$ Universidade Federal da Bahia (UFBA), Instituto de Biologia (IBIO), Laboratório de Ictiologia. Salvador, BA, Brasil. ORCID: http://orcid.org/0000-0002-4153-5648. E-mail: leonardoufcg.bio@hotmail.com (corresponding author)

${ }^{4}$ Universidade Federal do Rio Grande do Norte (UFRN), Centro de Biociências (CB), Departamento de Botânica e Zoologia (DBEZ), Laboratório de Ictiologia Sistemática e Evolutiva. Natal, RN, Brasil. ORCID: http://orcid.org/0000-0003-2405-7039. E-mail: silviayasminlcosta@gmail.com

${ }^{5}$ Centro Universitário Maurício de Nassau (UNINASSAU). João Pessoa, PB, Brasil. ORCID: http://orcid.org/0000-0003-2528-660X.E-mail: paulahonorio_bio@yahoo.com.br

\begin{abstract}
Tambaba environmentally protected area is situated on the south coast of Paraíba State, within the Atlantic forest biome of the northeastern region in Brazil. The Tambaba environmentally protected area consists of a series of independent drainages: Graú, Mucatú, and Bucatú river micro-basins, and Caboclo River sub-basin that belongs to Gurugi River micro-basin. Ichthyological samples were collected in five scientific expeditions between months of June and July in 2015. Twenty-nine sites from different habitats (e.g., spanning tributaries, streams, rivers, and estuaries) were accessed for sampling. A total of 44 species distributed within 38 genera, 25 families, and 17 orders were assigned to the Tambaba hydrographic region. Freshwater species comprised $36 \%(n=16)$ and marine-estuarine species $64 \%(n=28)$ of the total collected specimens. Two invasive species occur in the freshwater sites: Cichla monoculus and Poecilia reticulata. Cheirodon jaguaribensis, Cichlasoma orientale, and Crenicichla brasiliensis are endemic to the Brazilian Northeast region with the first species restricted to the Northeast Caatinga and Coastal drainages hydrographic ecoregion.
\end{abstract}

Key-Words. Atlantic forest ichthyofaunal; Endemism; Northeastern Caatinga, Coastal Drainages.

\section{INTRODUCTION}

The Atlantic Florest originally extended from the Rio Grande do Norte State (Northeastern region of Brazil) to the Rio Grande do Sul (Southern region) in Brazil. Throughout its distribution exhibits several types and subtypes of tropical and subtropical forests, comprising the second largest forest in South America (Gouveia et al., 2017). Preservation and conservation of the Atlantic Forest rivers and ichthyofauna are imperative due to its high endemicity rate (e.g., Gomiero \& Braga, 2006; Oyakawa et al., 2006; Menezes et al., 2007; Miranda, 2012; Gouveia et al., 2017) and exclusive ecological characteristics (e.g., Barbosa \& Costa, 2012; Pereira et al., 2012). Menezes et al. (2007) listed 325 freshwater fish species for a portion of
Atlantic forest in the Brazilian southeastern region. These authors called attention to the lack of taxonomic data related to the fish fauna for the Atlantic forest in the Brazilian northeast region; Abilhoa et al. (2011) recorded 269 freshwater species for streams in this region through data taken from the literature, and Camelier \& Zanata (2014) recognized 169 native freshwater species for the northeastern Atlantic Forest ecoregion. Many species were recently described within this region (Barbosa \& Costa, 2012; Pereira et al., 2012; Zanata \& Pitanga, 2016; Craig et al., 2017; de Pinna et al., 2018; Burger et al., 2019) with achievements of several related studies on the systematics and biogeography of the continental ichthyofauna of the Forest Atlantic.

The Atlantic forest biome requires conservation efforts through the creation of conservation 
units (UCs) throughout its area of extension in relation to its high diversity and accelerated loss and fragmentation of the original habitat (Almeida, 2016). Despite having the largest number of environmentally protected areas among the South American regions and increased creation of reserves and natural parks in recent years, the conservation effort in the area is still insufficient (Tabarelli et al., 2005; Almeida, 2016). Tambaba environmentally protected area (APA) is situated on the south coast of Paraíba State in Northeast Brazil within the Atlantic forest biome. This conservation unit (UC) was regulated in 2002 through the State Act (№ 22.882) and assigned to the category of conservation unities for sustainable use in order to guarantee compatibility between the sustainable usage of the natural resources and nature conservation as defined in the principal action plan for effective protection of the local fauna and flora (Costa, 2002).

A complex of small littoral hydrographic basins covers the hydrography of the Tambaba Environmentally Protected Area, located in the Northeastern Caatinga and Coastal Drainages - NCCD ecoregion (sensu Abell et al., 2008). Several studies focused on assessing the ichthyofauna of hydrographic basins from the NCCD (e.g., Rosa et al., 2003; Ramos et al., 2005; Paiva et al., 2014; Silva et al., 2014; Rodrigues-Filho et al., 2016; Teixeira et al., 2017; Gouveia et al., 2017; Oliveira-Silva et al., 2018; Ramos et al., 2018). However, with exception to Paiva et al. (2014) and Gouveia et al. (2017), the diversity of fishes within the Atlantic forest biome of this ecoregion was not yet investigated. Thus, the present study aimed to provide an inventory of the ichthyofauna from the river basins present in the Tambaba Environmentally Protected Area, contributing towards the taxonomic knowledge related to the fish fauna of the Atlantic Forest biome in the NCCD ecoregion.

\section{MATERIAL AND METHODS}

\section{Study area}

Tambaba Environmentally Protected Area is located in the micro-region of the south coast of Paraíba State, Brazil between $07^{\circ} 25^{\prime} 00^{\prime \prime} \mathrm{S}$ and $07^{\circ} 16^{\prime} 30^{\prime \prime} \mathrm{S}$ and $34^{\circ} 55^{\prime} 00^{\prime \prime} \mathrm{W}$ and $34^{\circ} 47^{\prime} 30^{\prime \prime} \mathrm{W}$, incorporating the municipalities of Conde, Pitimbú, and Alhandra within the Mata Paraibana mesoregion (Almeida et al., 2008). It comprises $114,46 \mathrm{~km}^{2}$ of total area extension, with its geographical limits defined by the local hydrographic basins (Fig. 1).

Graú, Mucatú and Bucatú river micro-basins and the Caboclo River sub-basin with the latter belonging to the Gurugi River micro-basin are located in the Tambaba Environmentally Protected Area (AESA, 2004). Graú River basin has 18,304 km of extension and its main course discharges at the north of Bela beach between Pitimbu and Conde municipalities. Mucatú River micro-basin has $9,690 \mathrm{~km}$ of extension and releases in the estuary of Bela beach in Pitimbu municipality. Bucatu River micro-basin extends approximately 3,265 km and it comprises a small drainage system located on the coast of Tabatinga beach in Conde municipality. Caboclo River sub-basin, a tributary of Gurugi River basin, comprises $6,435 \mathrm{~km}$ of extension and discharges in the main course of Gurugi River that later discharges at Jacumã beach in Conde municipality.

\section{Data collection}

Five scientific expeditions were undertaken in the hydrographic basins in Tambaba Environmentally Protected Area in June (three) and July (two) 2015. Sampling took place at 29 sites covering streams, rivers and estuaries in the municipalities of Alhandra, Conde, and Pitimbu (Fig. 1, Table 1). Of these, 13 sampling sites are located at Graú River basin, seven to Mucatú River basin, five to Bucatú River basin and four to the Caboclo River sub-basin in the Gurugi River basin. Specimens from the fish collection of Universidade Federal da Paraíba (UFPB) were also examined.

Specimens were collected using seine nets $(4 \mathrm{~m}$ length, $5 \mathrm{~mm}$ mesh size; $10 \mathrm{~m}$ length, $5 \mathrm{~mm}$ mesh size; $20 \mathrm{~m}$ length, $12 \mathrm{~mm}$ mesh size), cast nets ( $20 \mathrm{~mm}$ mesh size), gillnets (10 m length, $20 \mathrm{~mm}$ mesh size) and dip nets (5 $\mathrm{mm}$ mesh size). Specimens were then anesthe-

Table1. List of sampling sites in the Tambaba APA, Paraíba State, Brazil.

\begin{tabular}{|c|c|c|}
\hline ID & Sampling sites & Geographical Coordinates \\
\hline 1 & Mucatú stream, Mucatú village, Pitimbu & $07^{\circ} 23^{\prime} 19.1^{\prime \prime} \mathrm{S} ; 34^{\circ} 51^{\prime} 41.0^{\prime \prime} \mathrm{W}$ \\
\hline 2 & Stream in Mucatú village, Pitimbu & $07^{\circ} 23^{\prime} 06.0^{\prime \prime} \mathrm{S} ; 34^{\circ} 51^{\prime} 52.1^{\prime \prime} \mathrm{W}$ \\
\hline 3 & Graú River, under bridge at PB-008 road, Pitimbu & $07^{\circ} 21^{\prime} 04.2^{\prime \prime} \mathrm{S} ; 34^{\circ} 49^{\prime} 04.4^{\prime \prime} \mathrm{W}$ \\
\hline 4 & Andreza River, Andreza village, Pitimbu & $07^{\circ} 20^{\prime} 38.2^{\prime \prime} \mathrm{S} ; 34^{\circ} 50^{\prime} 52.3^{\prime \prime} \mathrm{W}$ \\
\hline 5 & Tributary of Andreza River, Pitimbu & $07^{\circ} 20^{\prime} 51.4^{\prime \prime} \mathrm{S} ; 34^{\circ} 50^{\prime} 44.5^{\prime \prime} \mathrm{W}$ \\
\hline 6 & Tributary of Graú River, PB-008, Pitimbu & $07^{\circ} 22^{\prime} 19.9^{\prime \prime} \mathrm{S} ; 34^{\circ} 49^{\prime} 19.0^{\prime \prime} \mathrm{W}$ \\
\hline 7 & Riacho do Boi stream, tributary of Mucatú River, Pitimbu & $07^{\circ} 24^{\prime} 37.2^{\prime \prime} \mathrm{S} ; 34^{\circ} 50^{\prime} 45.7^{\prime \prime} \mathrm{W}$ \\
\hline 8 & $\begin{array}{l}\text { Riacho do Boi stream, tributary of Mucatú, Nova Vida village, } \\
\text { Pitimbu }\end{array}$ & $.0 " \mathrm{~W}$ \\
\hline 9 & Riacho do Boi stream, tributary of Mucatú River, Pitimbu & $07^{\circ} 24^{\prime} 04.1^{\prime \prime} \mathrm{S} ; 34^{\circ} 49^{\prime} 58.6^{\prime \prime} \mathrm{W}$ \\
\hline 10 & Estuary of Graú River, Pitimbu & $07^{\circ} 22^{\prime} 42.4^{\prime \prime} \mathrm{S} ; 34^{\circ} 48^{\prime} 16.3^{\prime \prime} \mathrm{W}$ \\
\hline 11 & Graú River mouth, Bela beach, Pitimbu & $07^{\circ} 23^{\prime} 13.6^{\prime \prime} \mathrm{S} ; 34^{\circ} 48^{\prime} 13.7^{\prime \prime} \mathrm{W}$ \\
\hline 12 & Mucatú River, Pitimbu & $07^{\circ} 23^{\prime} 36.1^{\prime \prime} \mathrm{S} ; 34^{\circ} 49^{\prime} 57.7^{\prime \prime} \mathrm{W}$ \\
\hline 13 & Graú River, Pitimbu & $07^{\circ} 20^{\prime} 52.1^{\prime \prime} \mathrm{S} ; 34^{\circ} 48^{\prime} 47.7^{\prime \prime} \mathrm{W}$ \\
\hline 14 & $\begin{array}{l}\text { Tributary of Graú River, between Mata do Chica and Igarapú } \\
\text { villages, Alhandra }\end{array}$ & $07^{\circ} 19^{\prime} 09.6^{\prime \prime} \mathrm{S} ; 34^{\circ} 53^{\prime} 21.5^{\prime \prime} \mathrm{W}$ \\
\hline 15 & Igarapú River, Alhandra & $07^{\circ} 18^{\prime} 38.9^{\prime \prime} \mathrm{S} ; 34^{\circ} 54^{\prime} 14.2^{\prime \prime} \mathrm{W}$ \\
\hline 16 & Tributary of Graú River, Alhandra & $07^{\circ} 20^{\prime} 03.0^{\prime \prime} \mathrm{S} ; 34^{\circ} 53^{\prime} 34.7^{\prime \prime} \mathrm{W}$ \\
\hline 17 & Tributary of Graú River. Alhandra & $07^{\circ} 20^{\prime} 09.9^{\prime \prime} \mathrm{S} ; 34^{\circ} 52^{\prime} 29.4^{\prime \prime} \mathrm{W}$ \\
\hline 18 & $\begin{array}{l}\text { Graú River, under bridge of Alhandra road - Jacumã, } \\
\text { Alhandra }\end{array}$ & $07^{\circ} 20^{\prime} 18.5^{\prime \prime} \mathrm{S} ; 34^{\circ} 51^{\prime} 53.4^{\prime \prime} \mathrm{W}$ \\
\hline 19 & Jangada stream, tributary of Graú River, Pitimbu & $07^{\circ} 20^{\prime} 50.1^{\prime \prime} \mathrm{S} ; 34^{\circ} 51^{\prime} 18.9^{\prime \prime} \mathrm{W}$ \\
\hline 20 & Estuary of Mucatú River, Bela beach, Pitimbu & $07^{\circ} 23^{\prime} 57.8^{\prime \prime} \mathrm{S} ; 34^{\circ} 48^{\prime} 21.0^{\prime \prime} \mathrm{W}$ \\
\hline 21 & Left side of source from Bucatú River, Conde & $07^{\circ} 19^{\prime} 37.6^{\prime \prime} \mathrm{S} ; 34^{\circ} 49^{\prime} 22.3^{\prime \prime} \mathrm{W}$ \\
\hline 22 & Bucatú River, Conde & $07^{\circ} 19^{\prime} 18.0^{\prime \prime} \mathrm{S} ; 34^{\circ} 48^{\prime} 46.2^{\prime \prime} \mathrm{W}$ \\
\hline 23 & Right side of source from Bucatú River, Conde & $07^{\circ} 18^{\prime} 22.0^{\prime \prime} \mathrm{S} ; 34^{\circ} 49^{\prime} 09.9^{\prime \prime} \mathrm{W}$ \\
\hline 24 & Estuary of Bucatú River, under bridge of PB-008 road, Conde & $07^{\circ} 18^{\prime} 48.1^{\prime \prime} \mathrm{S} ; 34^{\circ} 48^{\prime} 30.4^{\prime \prime} \mathrm{W}$ \\
\hline 25 & Estuary of Bucatú River, Tabatinga beach, Conde & $07^{\circ} 18^{\prime} 43.5^{\prime \prime} \mathrm{S} ; 34^{\circ} 48^{\prime} 09.0^{\prime \prime} \mathrm{W}$ \\
\hline 26 & Tributary of Caboclo River, Conde & $07^{\circ} 17^{\prime} 42.0^{\prime \prime} \mathrm{S} ; 34^{\circ} 50^{\prime} 14.9^{\prime \prime} \mathrm{W}$ \\
\hline 27 & Tributary of Caboclo River, Conde & $07^{\circ} 18^{\prime} 13.8^{\prime \prime} \mathrm{S} ; 34^{\circ} 50^{\prime} 22.9^{\prime \prime} \mathrm{W}$ \\
\hline 28 & Caboclo River, tributary of Gurugi River, Conde & $07^{\circ} 18^{\prime} 22.0^{\prime \prime} \mathrm{S} ; 34^{\circ} 50^{\prime} 34.5^{\prime \prime} \mathrm{W}$ \\
\hline 29 & Caboclo River, tributary of Gurugi River, Conde & $07^{\circ} 17^{\prime} 44.9^{\prime \prime} \mathrm{S} ; 34^{\circ} 50^{\prime} 18.4^{\prime \prime} \mathrm{W}$ \\
\hline
\end{tabular}




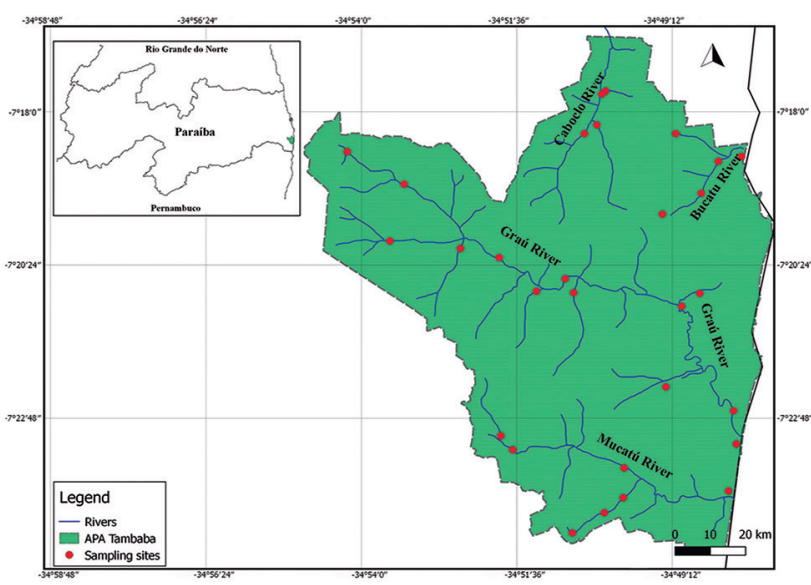

Figure 1. Map of Tambaba environmentally protected area (green area) in Paraíba State, Brazil, displaying the sampling sites (red dots) in Graú, Mucatú and Bucatú River basins, Caboclo River sub-basin and Gurugi River basin.

tized in eugenol solution diluted in alcohol and water, and then transferred to $10 \%$ formaldehyde for fixation. Later, scientific curatorial standards were undertaken such as specimen fixation in formaldehyde for a minimum of eight days, preservation in $75^{\circ} \mathrm{GL}$ ethyl alcohol solution, lot and specimen labeling, according to the methods of Malabarba \& Reis (1987). Photographs of fresh specimens were taken whenever possible using a digital camera model Canon PowerShot SX60 HS. Sorting and taxonomic identification of specimens and subsequent labeling were performed at the Laboratório de Sistemática e Morfologia de Peixes of the Universidade Federal da Paraíba (LASEP/UFPB). Lots and specimens were registered and deposited at the UFPB Ichthyological Collection. Species identification was based on studies of Araújo et al. (2004), Britski et al. (1984), Figueiredo \& Menezes (2000), Kullander (1988), Ploeg (1991), Ramos (2012) and Ramos et al. (2018). Taxonomic classification follows Fricke et al. (2019).

\section{RESULTS}

A total of 36 species were identified through examination of 1,124 specimens collected in the Tambaba APA (Figs. 2, 3, 4, and 5). In addition, eight species were identified based on the analysis of 54 specimens (23 lots) from the UFPB fish collection collected in the Graú River estuary in 2014. Thus, 44 species are recognized in the Tambaba APA hydrographic basins and are classified within 38 genera, 25 families, and 17 orders (Table 2). Of these, $36 \%(n=16)$ are from freshwater and $64 \%(n=28)$ are from estuarine-marine sites. Cichla monoculus Spix \& Agassiz, 1831, the "tucunaré", and Poecilia reticulata Peters, 1859 are invasive species in the freshwater sites. Cheirodon jaguaribensis Fowler, 1941, Cichlasoma orientale Kullander, 1983, and Crenicichla brasiliensis (Block, 1792) are endemic to the Brazilian northeast region, in which the first species is restricted to the NCCD hydrographic ecoregion.

The most abundant freshwater species in the hydrographic basins in Tambaba Environmentally Protected
Area are: Hemigrammus unilineatus (Gill, 1858) (32\% of total collected specimens), Poecilia vivipara Bloch \& Schneider, 1801 (27\%) and Astyanax aff. bimaculatus (Linnaeus, 1758) (11\%). Poecilia vivipara is a broadly distributed species that occurrs in 19 out of 29 sampling sites, and it is followed by Geophagus brasiliensis (Quoy \& Gaimard, 1824) that occurs in 13 sampling sites and Astyanax bimaculatus and Hoplias aff. malabaricus (Bloch, 1794) in 12 sampling sites. Characiformes are the largest freshwater order with seven species (16\% of total), with Characidae being the most speciose family represented by four autochthonous species. Cichliformes is the second largest freshwater order representing $9 \%$ of total collected species $(n=4)$, three autochthonous and one allochthonous species, all belonging to the family Cichlidae.

Atherinella brasiliensis (Quoy \& Gaimard, 1825) (with 8\%), Mugil curema Valenciennes, 1836 (3\%), and Eucinostomus argenteus Baird \& Girard, 1855 (3\%) correspond to the most abundant estuarine-marine species. Perciformes is the largest marine-estuarine order, representing $20 \%$ (9 species) while Gobiiformes is the second largest order with $14 \%$ of total species $(n=6)$, of which Gobiidae is the most speciose family $(n=4)$ among the marine-estuarine representatives.

Other orders comprise Pleuronectiformes with 9\%, Cyprinodontiformes, Tetraodontiformes and Syngnathiformes 5\% each, Atheriniformes, Blenniiformes, Clupeiformes, Gymnotiformes, Myliobatiformes, Mugiliformes, Siluriformes and Synbranchiformes have one species each, representing $4 \%$ of the total species (Table 2).

Among the species recognized herein, none are currently classified as threatened species, according to the official list of threatened species of fishes and aquatic invertebrates from Brazil, Portaria MMA № 445, 17 December 2014, Ministério do Meio Ambiente (Brasil, 2014). Gymnura micrura (Bloch \& Schneider, 1801), and Lutjanus jocu (Bloch \& Schneider, 1801) are classified as Near Threatened (NT), and Cheirodon jaguaribensis, and Mugil curema are classified as Data Deficient (DD) (Brasil, 2014).

\section{DISCUSSION}

Freshwater fish species from Tambaba Environmentally Protected Area represent 16\% ( $n=15)$ of the 94 total species for the NCCD ecoregion (OliveiraSilva et al., 2018). Studies that were previously carried out in the nearby areas such as Torelli et al. (1997) and Gomes-Filho \& Rosa (2001) listed 22 and 21 freshwater species, respectively, in Gramame River basin within the NCCD ecoregion of the Atlantic forest biome. These authors recognized a higher number of freshwater species than those observed for Tambaba Environmentally Protected Area and this discrepancy is probably due to differences in the historical evolution factors of these drains or sampling efforts. Paiva et al. (2014) recognized 22 species of which 13 are freshwater species in the 
a
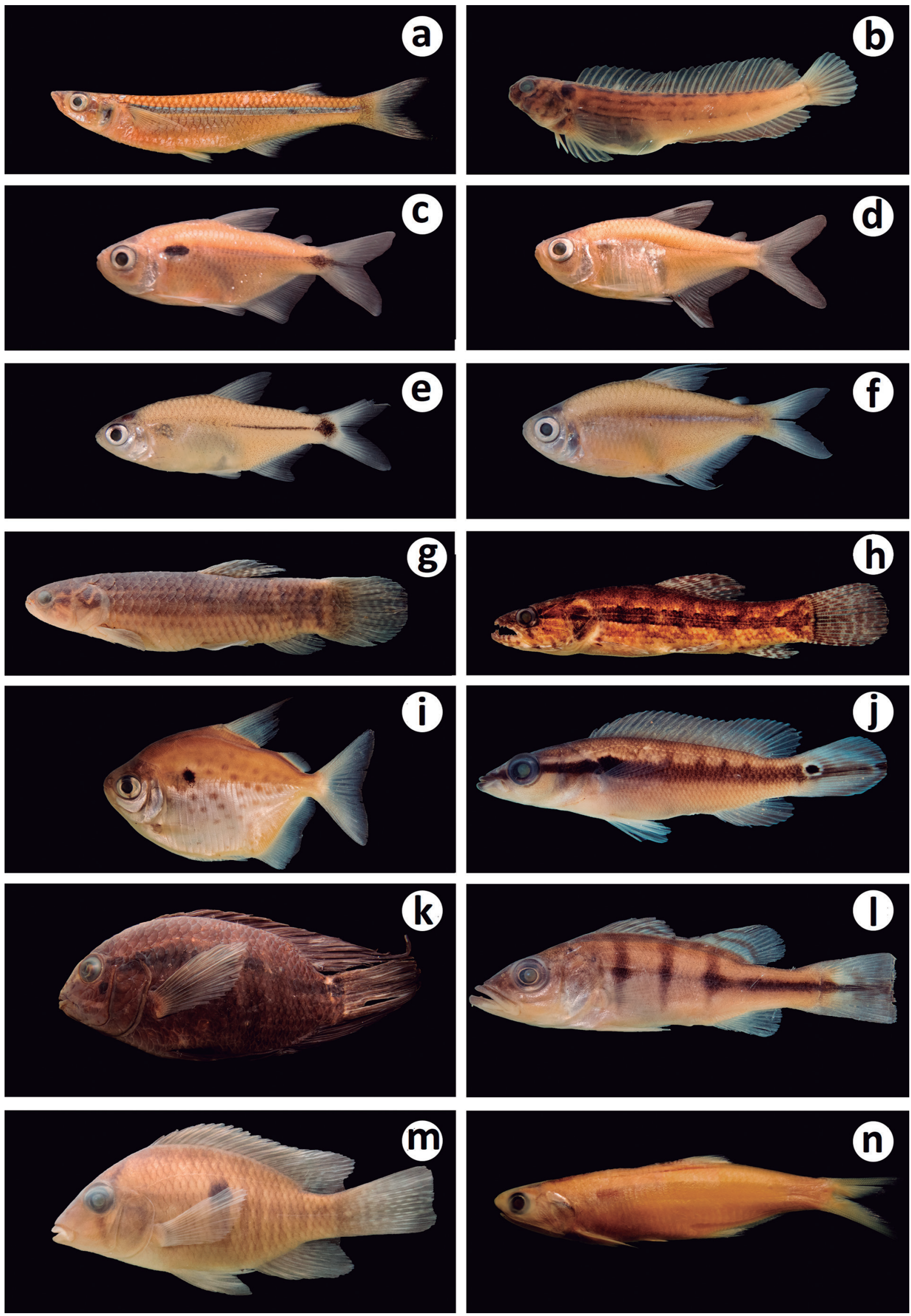

Figure 2. Species from Tambaba APA hydrographic basins: (a) Atherinella brasiliensis, $98.2 \mathrm{~mm} \mathrm{SL;} \mathrm{(b)} \mathrm{Omobranchus} \mathrm{punctatus,} 39.4 \mathrm{~mm} \mathrm{SL;} \mathrm{(c)} \mathrm{Astyanax} \mathrm{aff.} \mathrm{bimacu-}$ latus, $42.1 \mathrm{~mm} \mathrm{SL}$; (d) Hemigrammus unilineatus, $29.5 \mathrm{~mm} \mathrm{SL;} \mathrm{(e)} \mathrm{Compsura} \mathrm{heterura,} 27.7 \mathrm{~mm} \mathrm{SL;} \mathrm{(f)} \mathrm{Cheirodon} \mathrm{jaguaribensis,} 32.3 \mathrm{~mm} \mathrm{SL}$; (g) Erythrinus erythrinus, 91.6 mm SL; (h) Hoplias aff. malabaricus, $59.3 \mathrm{~mm} \mathrm{SL;} \mathrm{(i)} \mathrm{Metynnis} \mathrm{lippincottianus,} 51.7 \mathrm{~mm} \mathrm{SL;} \mathrm{(j)} \mathrm{Crenicichla} \mathrm{brasiliensis,} 35.3 \mathrm{~mm}$ SL; (k) Cichlasoma orientale, $60.6 \mathrm{~mm} \mathrm{SL} ;$ (I) Cichla monoculus, $55.6 \mathrm{~mm} \mathrm{SL;} \mathrm{(m)} \mathrm{Geophagus} \mathrm{brasiliensis,} 54.8 \mathrm{~mm} \mathrm{SL;} \mathrm{(n)} \mathrm{Lycengraulis} \mathrm{grossidens,} 60.3 \mathrm{~mm} \mathrm{SL}$. 

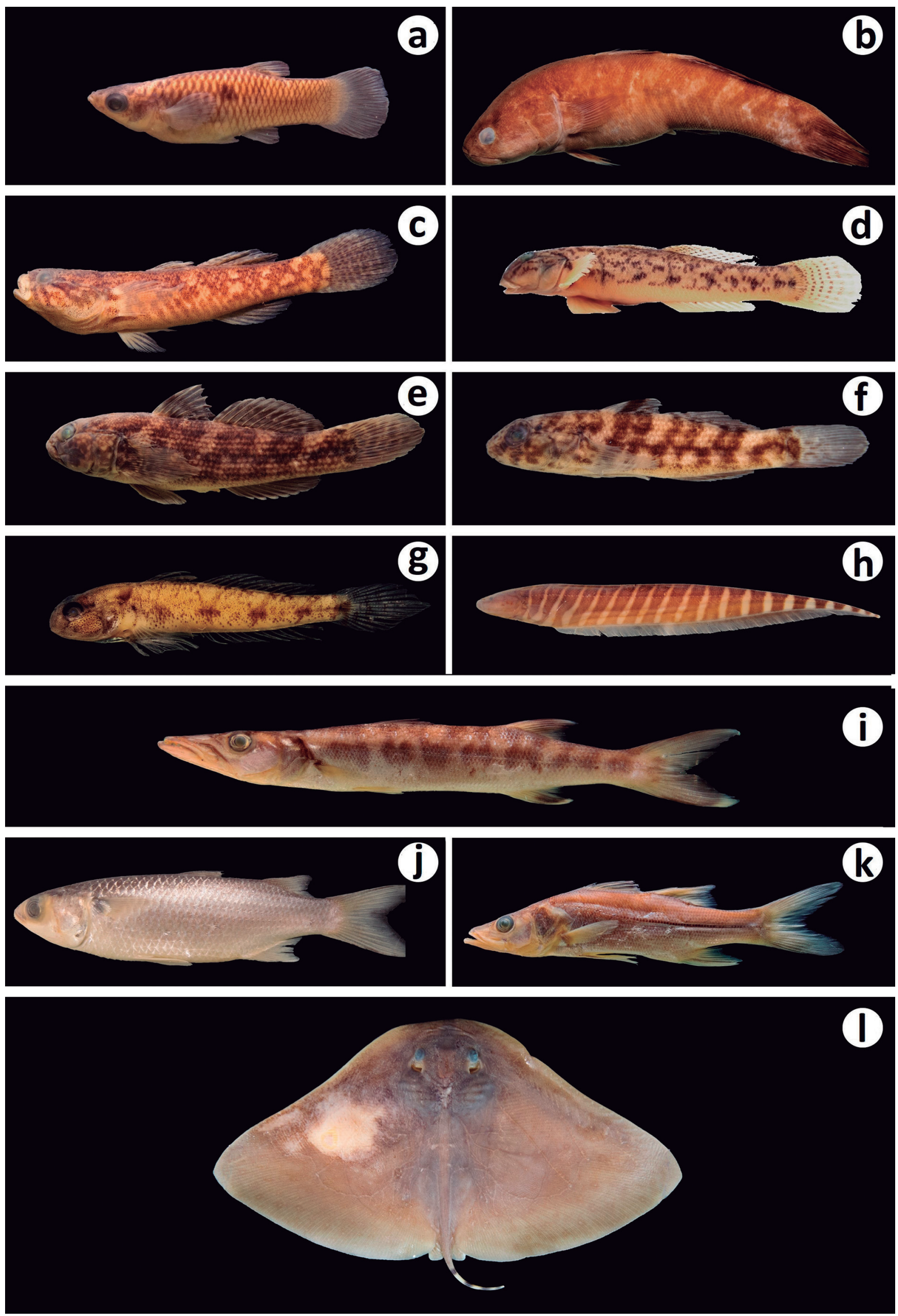

Figure 3. Species of fish from Tambaba APA hydrographic basins: (a) Poecilia vivipara, $32.7 \mathrm{~mm} \mathrm{SL}$; (b) Dormitator maculatus, $67.3 \mathrm{~mm} \mathrm{SL;} \mathrm{(c)} \mathrm{Eleotris} \mathrm{pisonis,}$ $65.7 \mathrm{~mm} \mathrm{SL}$; (d) Awaous tajasica, $70.6 \mathrm{~mm} \mathrm{SL}$; (e) Bathygobius soporator, $71.9 \mathrm{~mm} \mathrm{SL}$; (f) Evorthodus lyricus, $90.9 \mathrm{~mm} \mathrm{SL;} \mathrm{(g)} \mathrm{Ctenogobius} \mathrm{boleosoma,} 16.6 \mathrm{~mm} \mathrm{SL}$; (h) Gymnotus carapo, $86.1 \mathrm{~mm}$ TL; (i) Sphyraena barracuda, $153.8 \mathrm{~mm} \mathrm{SL}$; (j) Mugil curema, $86.9 \mathrm{~mm} \mathrm{SL;} \mathrm{(k)} \mathrm{Centropomus} \mathrm{undecimalis,} 121.8 \mathrm{~mm} \mathrm{SL;}$ (I) Gymnura micrura, $94.9 \mathrm{~mm} \mathrm{SL}$. 

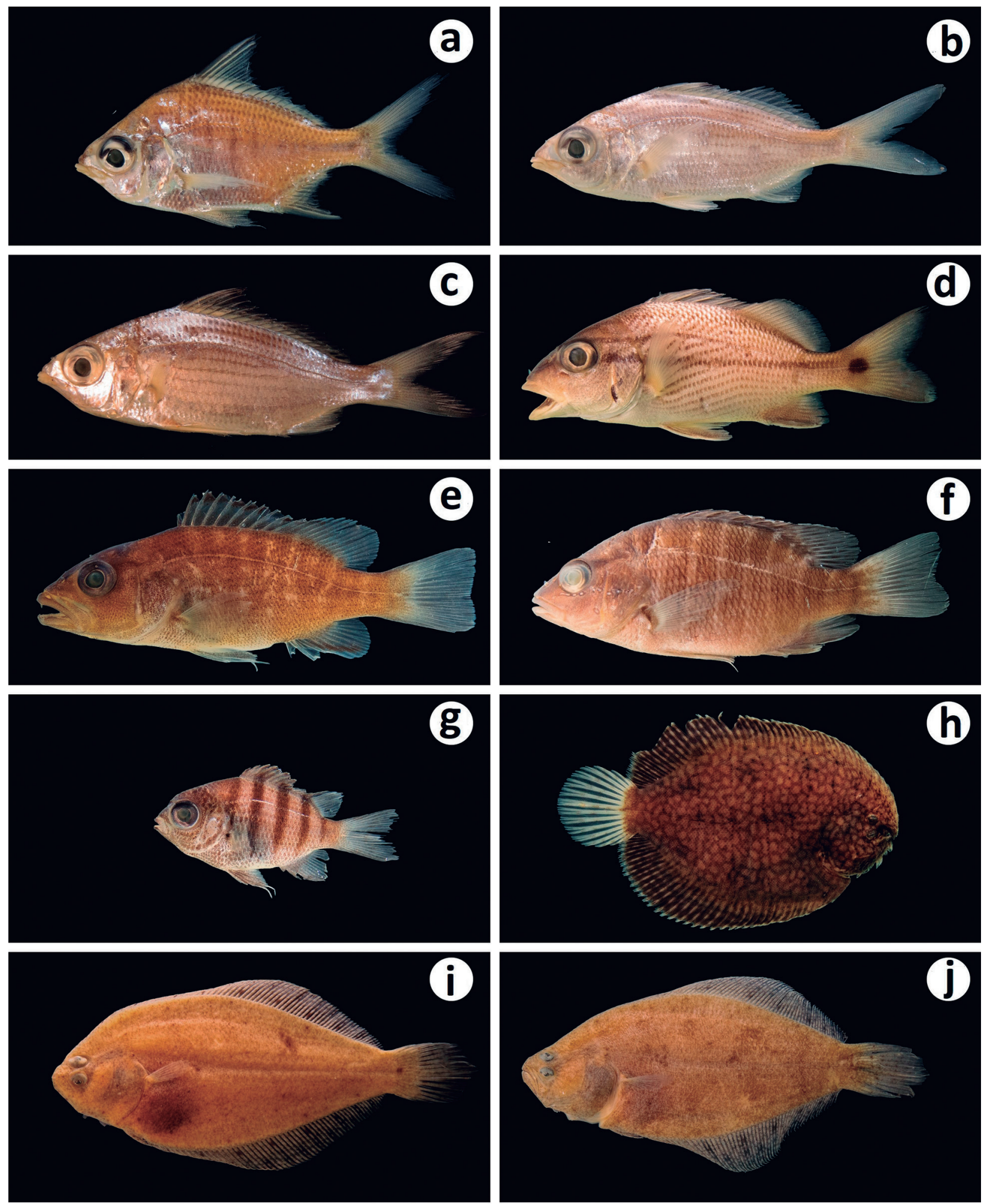

(k)

Figure 4. Species of fish from Tambaba APA hydrographic basins: (a) Diapterus auratus, $57.4 \mathrm{~mm} \mathrm{SL;} \mathrm{(b)} \mathrm{Eucinostomus} \mathrm{argenteus,} 69.7 \mathrm{~mm} \mathrm{SL;} \mathrm{(c)} \mathrm{Eucinostomus}$ gula, 61.4 mm SL; (d) Haemulon aurolineatum, 90.2 mm SL; (e) Lutjanus alexandrei, 55.6 mm SL; (f) Lutjanus jocu, 45.6 mm SL; (g) Abudefduf saxatil, 17.8 mm SL; (h) Trinectes inscriptus, 46.9 mm SL; (i) Citharichthys sp., 95.9 mm SL; (j) Citharichthys spilopterus, $103.1 \mathrm{~mm} \mathrm{SL;} \mathrm{(k)} \mathrm{Synbranchus} \mathrm{aff.} \mathrm{marmoratus,} 315.3 \mathrm{~mm}$ TL. 

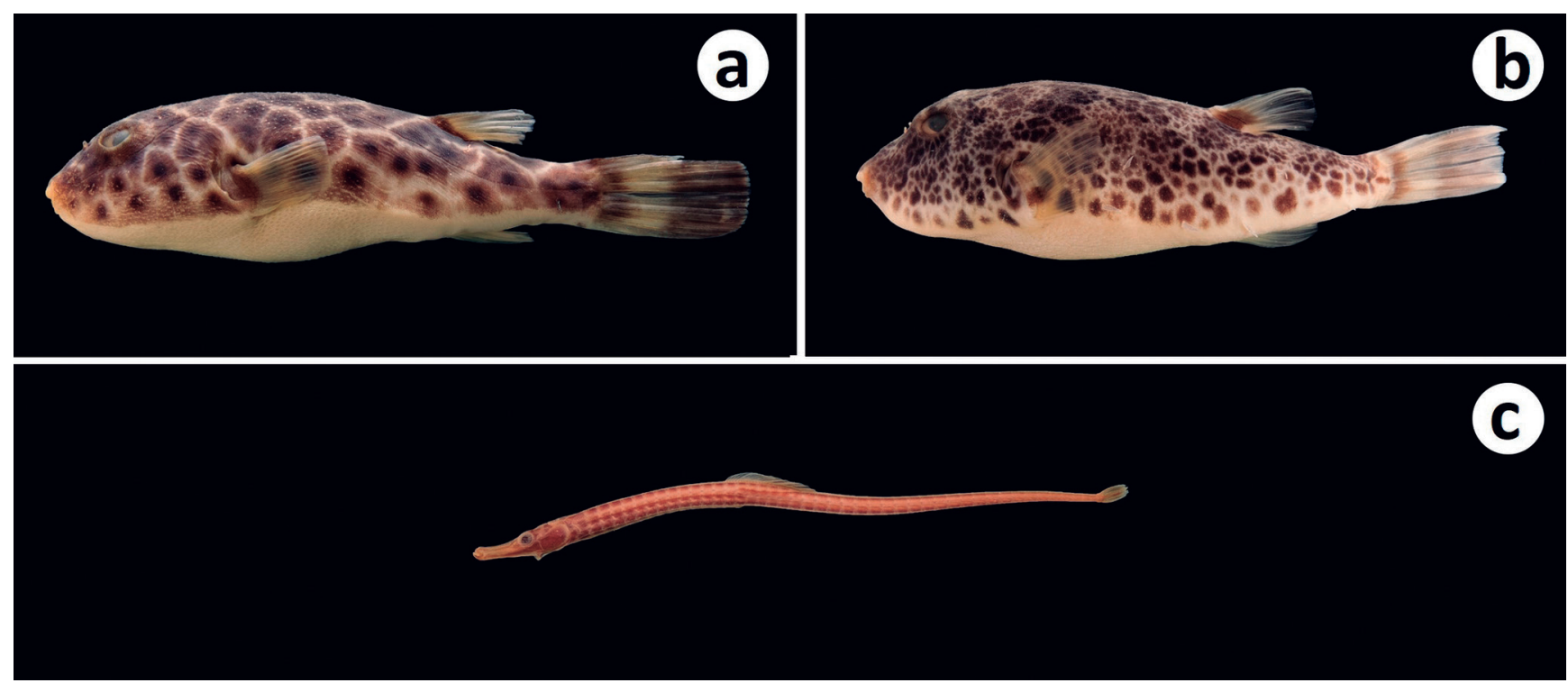

Figure 5. Species of fish from Tambaba APA hydrographic basins: (a) Sphoeroides spengleri, $90.3 \mathrm{~mm} \mathrm{SL;} \mathrm{(b)} \mathrm{Sphoeroides} \mathrm{testudineus,} 73.3 \mathrm{~mm}$ SL; (c) Syngnathus pelagicus, $153.8 \mathrm{~mm} \mathrm{SL}$.

Pratagi River micro-basin in Rio Grande do Norte State, Brazil. Gouveia et al. (2017) registered 18 freshwater species, distributed within seven families and five orders in Guaribas Biological Reserve UC and surrounding areas from the Camaratuba River hydrographic basin. These studies are incongruent with the present analysis but it is noticed a similar number of species to that those registered for the coastal rivers of the Atlantic Forest in NCCD ecoregion.

Characiformes, Characidae is the most representative group among the freshwater fishes in the Tambaba APA. This result is congruent with previous studies on the freshwater ichthyofauna from the NCCD hydrographic basins (e.g., Torelli et al., 1997; Ramos et al., 2005; Paiva et al., 2014; Silva et al., 2014; Rodrigues-Filho et al., 2016; Costa et al., 2017; Gouveia et al., 2017; Teixeira et al., 2017; Oliveira-Silva et al., 2018; Ramos et al., 2018). These results differ from the general pattern of dominance that is noticed for the NCCD ecoregion as provided in Lima et al. (2017); Siluriformes has the highest number of species (143 vs. 132 Characiformes). However, species of Characiformes dominate when each basin of the NCCD is evaluated individually as pointed out in Oliveira-Silva et al. (2018), and according to the authors the greatest number of Siluriformes for this ecoregion occurs due to the greater number of endemic species of this order for each individual basin that would explain the apparent dominance of Siluriformes when these numbers are put together.

The three most abundant freshwater species, Hemigrammus unilineatus, Astyanax bimaculatus (Characidae), and Poecilia vivipara (Poeciliidae), are small-sized autochthonous species. The first two species belong to the group commonly known as "piabas" (in Portuguese), which do not provide any commercial interest to most of the local population. Local fishermen often employ these species as bait for capturing larger species. The abundance of "piabas" is due to schooling behavior, which facilitates the collection of specimens in the field
(Ramos, 2012). A small-sized species, Poecilia vivipara, popularly known as "guarú", "guru" or "barrigudinho" also holds no commercial interest to local fishing communities. These three species combined correspond to $67 \%$ of the total captured specimens. Small-sized species are often used in the aquarium trade, as is the case for species from Characidae and Poeciliidae (Nelson, 2006; Magalhães \& Jacobi, 2013), although this secondary activity was not observed within the Tambaba APA.

Hemigrammus unilineatus was recognized in coastal rivers from the Atlantic forest biome in the Brazilian northeast region (Buckup et al., 2007; Menezes et al., 2007; Langeani et al., 2009; Gouveia et al., 2017) even though the type-locality of this species is in Trinidad Island, West Indies (Reis et al., 2003). Historical relationships between the Atlantic and Amazonian forests explain the natural distribution of this species in the Brazilian northeast region (Wang et al., 2004; Menezes et al., 2007; Dagosta \& de Pinna, 2017; Teixeira et al., 2017).

In the marine-estuarine ichthyofauna, Perciformes is one of the largest groups of the study area as previously observed in other Brazilian northeastern estuaries (e.g., Teixeira \& Falcão, 1992; Alves \& Soares-Filho, 1996; Santos, 2000; Araújo et al., 2000; Paiva et al., 2008; ReisFilho et al., 2010; Oliveira-Silva et al., 2008; Teixeira et al., 2017). Among the species recognized for this order, the occurrence of Centropomus undecimalis (known as "robalo-flexa" or "camorim") must be highlighted due to its commercial importance such as it is noticed for most sea bass species in the artisanal, industrial and recreational fisheries (Fujimoto et al., 2009). This species occurs from North Carolina (U.S.A.) to Uruguay, including Gulf of Mexico and Caribbean Sea (Fricke et al., 2019).

Atherinella brasiliensis and Mugil curema, popularly known as "sauna" and "tainha" respectively, are the most abundant marine-estuarine species that also exhibit schooling behavior, which explains the large number of specimens collected. The former species is considered generalized, opportunistic omnivorous feeders in estuar- 
Table 2. List of species from Tambaba APA, Paraíba State, Brazil observed in the Graú, Mucatú, and Bucatú river basins, Caboclo River sub-basin and Gurugi River basin. $\mathrm{DD}=$ deficient data, $\mathrm{LC}=$ Last concern, $\mathrm{NE}=$ not evaluated, UFPB $=$ Universidade Federal da Paraíba, UFRN = Universidade Federal do Rio Grande do Norte, NT $=$ not threatened.

\begin{tabular}{|c|c|c|c|}
\hline ORDER/Family/species & PHISIOLOGY & STATUS & VOUCHER \\
\hline \multicolumn{4}{|l|}{ ATHERINIFORMES } \\
\hline \multicolumn{4}{|l|}{ Atherinopsidae } \\
\hline Atherinella brasiliensis (Quoy \& Gaimard, 1825) & Marine-estuarine & LC & UFPB 11559 \\
\hline \multicolumn{4}{|l|}{ BLENNIIFORMES } \\
\hline \multicolumn{4}{|l|}{ Blenniidae } \\
\hline Omobranchus punctatus (Valenciennes, 1836) & Marine-estuarine & LC & UFPB 11569 \\
\hline \multicolumn{4}{|l|}{ CHARACIFORMES } \\
\hline \multicolumn{4}{|l|}{ Characidae } \\
\hline Astyanax aff. bimaculatus (Linnaeus 1758) & Freshwater & $\mathrm{LC}$ & UFPB 10418 \\
\hline Cheirodon jaguaribensis Fowler, 1941 & Freshwater & DD & UFPB 11617 \\
\hline Compsura heterura Eigenmann, 1915 & Freshwater & $\mathrm{LC}$ & UFPB 9790 \\
\hline Hemigrammus unilineatus (Gill, 1858) & Freshwater & NE & UFPB 10425 \\
\hline \multicolumn{4}{|l|}{ Erythrinidae } \\
\hline Erythrinus erythrinus (Bloch \& Schneider, 1801) & Freshwater & $\mathrm{LC}$ & UFPB 10431 \\
\hline Hoplias aff. malabaricus (Bloch, 1794) & Freshwater & LC & UFPB 10417 \\
\hline \multicolumn{4}{|l|}{ Serrasalmidae } \\
\hline Metynnis lippincottianus (Cope, 1870) & Freshwater & $\mathrm{LC}$ & UFPB 9906 \\
\hline \multicolumn{4}{|l|}{ CICHLIFORMES } \\
\hline \multicolumn{4}{|l|}{ Cichlidae } \\
\hline Crenicichla brasiliensis (Bloch, 1792) & Freshwater & $\mathrm{LC}$ & UFPB 10649 \\
\hline Cichlasoma orientale Kullander, 1983 & Freshwater & $\mathrm{LC}$ & UFPB 10686 \\
\hline Cichla monoculus Spix \& Agassiz, 1831 & Freshwater & $\mathrm{LC}$ & UFPB 10644 \\
\hline Geophagus brasiliensis (Quoy \& Gaimard, 1824) & Freshwater & LC & UFPB 10420 \\
\hline \multicolumn{4}{|l|}{ CLUPEIFORMES } \\
\hline \multicolumn{4}{|l|}{ Engraulidae } \\
\hline Lycengraulis grossidens (Spix \& Agassiz, 1829) & Marine-estuarine & $\mathrm{LC}$ & UFPB 9927 \\
\hline \multicolumn{4}{|l|}{ CYPRINODONTIFORMES } \\
\hline \multicolumn{4}{|l|}{ Poeciliidae } \\
\hline Poecilia reticulata Peters, 1859 & Freshwater & $\mathrm{LC}$ & UFPB 10688 \\
\hline Poecilia vivipara Bloch \& Schneider, 1801 & Freshwater & NE & UFPB 10416 \\
\hline \multicolumn{4}{|l|}{ GOBIIFORMES } \\
\hline \multicolumn{4}{|l|}{ Eleotridae } \\
\hline Dormitator maculatus (Bloch, 1792) & Marine-estuarine & LC & UFPB 10419 \\
\hline Eleotris pisonis (Gmelin, 1789) & Marine-estuarine & $\mathrm{LC}$ & UFPB 10421 \\
\hline \multicolumn{4}{|l|}{ Gobiidae } \\
\hline Awaous tajasica (Lichtenstein, 1822) & Marine-estuarine & $\mathrm{LC}$ & UFPB 10669 \\
\hline Bathygobius soporator (Valenciennes, 1837) & Marine-estuarine & $\mathrm{LC}$ & UFPB 9904 \\
\hline Evorthodus lyricus (Girard, 1858) & Marine-estuarine & LC & UFPB 9920 \\
\hline Ctenogobius boleosoma (Jordan \& Gilbert, 1882) & Marine-estuarine & $\mathrm{NE}$ & UFPB 9903 \\
\hline \multicolumn{4}{|l|}{ GYMNOTIFORMES } \\
\hline \multicolumn{4}{|l|}{ Gymnotidae } \\
\hline Gymnotus cf. darwini Campos-da-Paz \& de Santana, 2019 & Freshwater & $\mathrm{LC}$ & UFPB 10679 \\
\hline
\end{tabular}

ies with tolerance to several distinct environmental conditions (Contente et al., 2011). The second species also tolerates environments with different levels of salinity since it is a migratory species inhabiting the ocean in adult stage and estuaries while juvenile that functioning as nursery areas (Carvalho et al., 2007). Abundance of these marine-estuarine species is also noticed in other estuarine areas from the Northeastern region of Brazil as seen in Reis-Filho et al. (2010), Costa \& Camara (2012), Reis-Filho et al. (2012), and Campos et al. (2015). These species are of commercial importance to artisanal fisheries throughout the Brazilian coast (Soares-Filho et al., 2010).

\begin{tabular}{|c|c|c|c|}
\hline ORDER/Family/species & PHISIOLOGY & STATUS & VOUCHER \\
\hline \multicolumn{4}{|l|}{ MUGILIFORMES } \\
\hline \multicolumn{4}{|l|}{ Mugilidae } \\
\hline Mugil curema Valenciennes, 1836 & Marine-estuarine & DD & UFPB 11572 \\
\hline \multicolumn{4}{|l|}{ MYLIOBATIFORMES } \\
\hline \multicolumn{4}{|l|}{ Gymnuridae } \\
\hline Gymnura micrura (Bloch \& Schneider, 1801) & Marine-estuarine & NT & UFPB 11556 \\
\hline \multicolumn{4}{|l|}{ PERCIFORMES } \\
\hline \multicolumn{4}{|l|}{ Centropomidae } \\
\hline Centropomus undecimalis (Bloch, 1792) & Marine-estuarine & LC & UFPB 11561 \\
\hline \multicolumn{4}{|l|}{ Gerreidae } \\
\hline Diapterus auratus Ranzani, 1842 & Marine-estuarine & LC & UFPB 9919 \\
\hline Eucinostomus argenteus Baird \& Girard, 1855 & Marine-estuarine & LC & UFPB 11558 \\
\hline Eucinostomus gula (Quoy \& Gaimard, 1824) & Marine-estuarine & LC & UFPB 9902 \\
\hline \multicolumn{4}{|l|}{ Haemulidae } \\
\hline Haemulon aurolineatum Cuvier, 1830 & Marine-estuarine & LC & UFPB 11568 \\
\hline \multicolumn{4}{|l|}{ Lutjanidae } \\
\hline Lutjanus alexandrei Moura \& Lindeman, 2007 & Marine-estuarine & LC & UFPB 11562 \\
\hline Lutjanus jocu (Bloch \& Schneider, 1801) & Marine-estuarine & NT & UFPB 9917 \\
\hline \multicolumn{4}{|l|}{ Pomacentridae } \\
\hline Abudefduf saxatilis (Linnaeus, 1758) & Marine-estuarine & $\mathrm{LC}$ & UFPB 1566 \\
\hline \multicolumn{4}{|l|}{ Sphyraenidae } \\
\hline Sphyraena barracuda (Edwards, 1771) & Marine-estuarine & LC & UFPB 11560 \\
\hline \multicolumn{4}{|l|}{ PLEURONECTIFORMES } \\
\hline \multicolumn{4}{|l|}{ Achiridae } \\
\hline Trinectes inscriptus (Gosse, 1851) & Marine-estuarine & $\mathrm{LC}$ & UFPB 11571 \\
\hline Trinectes paulistanus (Miranda Ribeiro, 1915) & Marine-estuarine & LC & UFPB 9922 \\
\hline \multicolumn{4}{|l|}{ Paralichthyidae } \\
\hline Citharichthys sp. & Marine-estuarine & NE & UFPB 10671 \\
\hline Citharichthys spilopterus Günther, 1862 & Marine-estuarine & LC & UFPB 9910 \\
\hline \multicolumn{4}{|l|}{ SILURIFORMES } \\
\hline \multicolumn{4}{|l|}{ Callichthyidae } \\
\hline Megalechis thoracata (Valenciennes, 1840) & Freshwater & $\mathrm{NE}$ & UFPB 10654 \\
\hline \multicolumn{4}{|l|}{ SYNBRANCHIFORMES } \\
\hline \multicolumn{4}{|l|}{ Synbranchidae } \\
\hline Synbranchus aff. marmoratus Bloch, 1795 & Freshwater & NE & UFPB 10658 \\
\hline \multicolumn{4}{|l|}{ SYNGNATHIFORMES } \\
\hline \multicolumn{4}{|l|}{ Syngnathidae } \\
\hline Microphis brachyurus (Bleeker, 1854) & Marine-estuarine & LC & UFPB 9905 \\
\hline Syngnathus pelagicus Linnaeus, 1758 & Marine-estuarine & $\mathrm{LC}$ & UFPB 9916 \\
\hline \multicolumn{4}{|l|}{ TETRAODONTIFORMES } \\
\hline \multicolumn{4}{|l|}{ Tetraodontidae } \\
\hline Sphoeroides spengleri (Bloch, 1785) & Marine-estuarine & LC & UFPB 11557 \\
\hline Sphoeroides testudineus (Linnaeus, 1758) & Marine-estuarine & $\mathrm{LC}$ & UFPB 9909 \\
\hline
\end{tabular}

The occurrence of Cichla monoculus, the "tucunaré", is recorded in a single sampling site in Caboclo River, a tributary of Gurugi River in Conde municipality. The allochthonous species $C$. monoculus occurs originally along the riverbeds from the Rio Napo, Ucayali, Solimões-Amazonas, Araguari and Oiapoque (Reis et al., 2003). Species of Cichla have been largely introduced in the Brazilian hydrographic basins, especially in northeastern Brazil dams, through government fish breeding programmers and also in order to eliminate piranha species of Pygocentrus and Serrasalmus (Gurgel \& Oliveira, 1987; Leão et al., 2011). They have also been introduced intensively by 
recreational fisheries and are possibly responsible for local extinctions of native species (Leão et al., 2011). Cichla comprises a genus of carnivorous species with very aggressive predation behavior (Leão et al., 2011), which might cause a reduction in the abundance and threat the diversity of native species from hydrographic basins in Tambaba Environmentally Protected Area.

Deforestation and civil construction areas are evident in the mangroves from the estuaries of Graú, Mucatú, and Bucatú Rivers. Mangroves correspond to merely $2.43 \mathrm{~km}^{2}$ or $2.13 \%$ of the total area from Tambaba Environmentally Protected Area (Almeida et al., 2008), indicating a massive reduction of the native mangrove coverage when compared to other major hydrographic basins such as Mamanguape and Paraíba do Norte River basins, located in Paraíba State. Many marine fish species seasonally inhabit mangroves for feeding and reproduction while others utilize them permanently (Lowe-McConnell, 1999). Mangrove roots are often employed as nursery and refuge sites against predators for a variety of species for instance Lutjanus alexandrei Moura \& Lindeman, 2007, L. jocu, Mugil curema, Sphoeroides testudineus (Linnaeus, 1758), and Sphyraena barracuda (Edwards, 1771) that are observed in Tambaba Environmentally Protected Area (Osório et al., 2011). Mangroves and estuaries from Tambaba APA (comprising the Mucatú, Bucatú, and Graú Rivers) require eminent conservation management due to its ecological role to the aquatic fauna as feeding, nursery, and home grounds (Thayer et al., 1987).

The Atlantic forest biome is one of the world biodiversity hotspots characterized by its high endemism and richness of species and habitats, although it is currently under risk of extinction (Myers et al., 2000). The ichthyofauna assessment of Tambaba Environmentally Protected Area demonstrates the diversity of species present within its coastal and hydrographic limits which is of major ecological and conservational value as it is situated within the Atlantic forest biome in the northeastern region of Brazil. This environmentally protected area is a national and international renowned region because its scenic nature landscapes. This region has been under considerable and fast-growing urban development for touristic purposes, especially in the hospitality industry. Besides that, the production of agricultural stocks such as banana, sugar cane and bamboo in the inner limits of Tambaba Environmentally Protected Area also contributes to environmental pressures, including intensive deforestation and deterioration (Almeida et al., 2008). Agricultural activities as well as livelihood in the region, including livestock, sediment extraction, and civil construction also entails anthropogenic impacts in the hydrographic basins and surrounding areas resulting in deforestation of the riparian forest in many rivers and streams. These latter two activities also contribute to the deposition of chemical waste in the river basins.

Forests with origin in river bases are considered permanently protected areas (APPs), according to the Brazilian Forest Code (Law № 12.651/2012). Thus, the conservation efforts of river sources as well as the riparian forest associated to it are essential for the natural maintenance of water springs. Restoration of the natural environments through environmental and conservation management is crucial in order to reach the natural stability from Tambaba Environmentally Protected Area as proposed in Meneses et al. (2005), Almeida et al. (2008), and Sobrinho Jr. \& Araújo (2016). Finally, the results presented herein contribute to the taxonomic knowledge of the fish fauna from the Tambaba APA and more generally to the understanding of the ichthyological diversity of the NCCD ecoregion.

\section{ACKNOWLEDGEMENTS}

The authors thank Dr. Ricardo Rosa (UFPB) for supporting the access to data from the fish collection, Consultoria Ambiental Office 04 for the management plan in Tambaba Environmentally Protected Area, Ton Jones Anselmo for helping during field sampling, and Ana Carolina Figueiredo for borrowing a digital camera.

\section{REFERENCES}

Abell, R.; Thieme, M.L.; Revenga, C.; Bryer, M.; Kottelat, M.; Bogutskaya, N.; Coad, B.; Mandrak, N.; Contreras-Balderas, S.; Bussing, W.; Stiassny, M.L.J.; Skelton, P.; Allen, G.R.; Unmack, P.; Naseka, A.; NG, R.; Sindorf, N.; Robertson, J.; Armijo, E.; Higgins, J.V.; Heibel, T.J.; Wikramanayake, E.; Olson, D.; López, H.L.; Reis, R.E.; Lundberg, J.G.; Sabaj Pérez, M.H. \& Petry, P. 2008. Freshwater Ecoregions of the World: A New Map of Biogeographic Units for Freshwater Biodiversity Conservation. BioScience, 58: 403-414.

Abilhoa, V.; Braga, R.R.; Bornatowski, H. \& Vitule, J.R.S. 2011. Fishes of the Atlantic Rain Forest Streams: Ecological Patterns and Conservation. In: Grillo, 0. \& Venora, G. (Orgs.). Changing diversity in changing environment. Rijeka, Intech. p. 259-282.

Agência Executiva de Gestão de Águas (AESA). 2004. Proposta de Instituição do Comitê das Bacias Hidrográficas do Litoral Sul, conforme resolução № 1, de 31 de agosto de 2003, do conselho estadual de recursos hídricos do estado da Paraiba. Disponível em: http://www.aesa.pb.gov.br/aesa-website/ wp-content/uploads/2017/06/Proposta-de-Cria\%C3\%A7\%C3\%A30do-CBH-LS.pdf. Acesso em: 27/03/2018.

Almeida, D.S. 2016. Recuperação ambiental da Mata Atlântica. 3ed., revista e ampliada. Ilhéus, Editus. 200p.

Almeida, N.V.A.; Nishida, K. \& Lima, E.R.V. 2008. Sistema de Informação Geográfica na Avaliação da Vulnerabilidade Física da Área de Proteção Ambiental de Tambaba, PB. Gaia Scientia, 1(2): 73-87.

Alves, M.I.M. \& Soares-Filho, A.A. 1996. Peixes do estuário do Rio Jaguaribe (Ceará, Brasil): Aspectos Fisioecológicos. Ciência Agronômica, 27(1): 1-16.

Araújo, M.E.; Teixeira, J.M.C. \& Oliveira, A.M.E. 2000. Ictiofauna marinha do estado do Ceará, Brasil, III. Actinopterygii de estuários. Arquivos de Ciência do Mar, 33: 139-142.

Araújo, M.E.; Teixeira, J.M.C. \& Oliveira, A.M.E. 2004. Peixes estuarinos marinhos do Nordeste brasileiro: guia Ilustrado. Fortaleza, Editora UFC. 260p.

Barbosa, M.A. \& Costa, W.J.E.M. 2012. Trichomycterus puriventris (Teleostei: Siluriformes: Trichomycteridae), a new species of catfish from the Paraíba do Sul river basin, southeastern Brazil. Vertebrate Zoology, 62: 155-160.

Brasil. 2014. Lista Nacional Oficial de Espécies da Fauna Ameaçada de Extinção - Portaria № 443, de 17 de dezembro de 2014. Ministério do Meio Ambiente. Diário Oficial da União, Brasília, Seção 1(245): 121-130. 
Britski, H.A.; Sato, Y. \& Rosa, A.B.S. 1984. Manual de identificação de peixes da região de Três Marias. Brasília, Câmara dos Deputados/CODEVASF. 143p.

Buckup, P.A.; Menezes, N.A. \& Ghazzi, M.S. 2007. Catálogo das espécies de peixes de água doce do Brasil. Rio de Janeiro, Museu Nacional. 195p.

Burger, R.; Carvalho, F.R. \& Zanata, A.M. 2019. A new species of Astyanax Baird \& Girard (Characiformes: Characidae) from western Chapada Diamantina, Bahia, Brazil. Zootaxa, 4604(2): 369-380.

Camelier, P. \& Zanata, A.M. 2014. Biogeography of freshwater fishes from the Northeastern Mata Atlântica freshwater ecoregion: distribution, endemism, and area relationships. Neotropical lchthyology, 12(4):683-698.

Campos, D.M.A.R.; Silva, A.F.; Sales, N.S.; Oliveira, R.E.M.C.C. \& Pessanha, A.M.L. 2015. Trophic relationships among fish assemblages in a mudflat within Brazilian marine protected área. Brazilian Journal of Oceanography, 63(2): 135-146.

Carvalho, C.D.; Corneta, C.M. \& Uieda, V.S. 2007. Schooling behavior of Mugil curema (Perciformes: Mugilidae) in an estuary in southeastern Brazil. Neotropical Ichthyology, 5(1): 81-83.

Contente, R.F.; Stefanoni, M.F. \& Spach, H.L. 2011. Feeding ecology of the Brazilian silverside Atherinella brasiliensis (Atherinopsidae) in a subtropical estuarine ecosystem. Journal of the Marine Biological Association of the United Kingdom, 91(6): 1197-1205.

Costa, M.F. \& Camara, M.R. 2012. Diversity, abundance and seasonal variation of the ichthyofauna associated with shrimp farming in a tropical estuary in Northeastern Brazil. Marine Biodiversity, 42: 471-479.

Costa, S.Y.L.; Barbosa, J.E.L.; Viana, L.G. \& Ramos, T.P.A. 2017. Composition of the ichthyofauna in Brazilian semiarid reservoirs. Biota Neotropica, 17(3): 1-11.

Costa, W.J.E.M. 2002. Peixes anuais brasileiros: Diversidade e conservação. Curitiba: Ed. UFPR. 238p.

Craig, J.M.; Crampton, W.G. \& Albert, J.S. 2017. Revision of the polytypic electric fish Gymnotus carapo (Gymnotiformes, Teleostei), with descriptions of seven subspecies. Zootaxa, 4318(3): 401-438.

Dagosta, F.C.P. \& de Pinna, M.C.C. 2017. Biogeography of Amazonian fishes: deconstructing river basins as biogeographic units. Neotropical Ichthyology, 15(3): e170034[24].

Figueiredo, J.L. \& Menezes, N.A. 2000. Manual de peixes marinhos do Sudeste do Brasil. VI. Teleostei (5). São Paulo, Museu de Zoologia, USP.

Fricke, R.; Eschmeyer, W.N. \& Fong, J.D. 2019. Species by family/subfamily. [Internet]. San Francisco (CA): California Academy of Sciences; [cited 2019 Jan 31]. Available from: http://researcharchive.calacademy.org/ research/ichthyology/catalog/SpeciesByFamily.asp.

Fujimoto, R.D.; Santana, C.A.; Carvalho, W.L.C.; Diniz, D.G.; Barros, Z.M.N.; Varella, J.E.A.; Guimarães, D.F. 2009. Hematologia e parasitas metazoários de camurim (Centropomus undecimalis Bloch, 1792) na região Bragantina, Bragança, Pará. Boletim do Instituto de Pesca, 35(3): 441-450.

Gomes-Filho, G. \& Rosa, R.S. 2001. Inventário da ictiofauna da bacia do rio Gramame, Paraíba, Brasil. In:Watanabe, T. (Ed.). A bacia do Rio Gramame: biodiversidade, uso e conservação. João Pessoa, Prodema. p. 167-173.

Gomiero, L.M. \& Braga F.M.S. 2006. Diversity of the ichthyofauna in the Serra do Mar State Park - Núcleo Santa Virgínia, São Paulo, Brazil. Acta Scientiarum, Biological Sciences, 28: 213-218.

Gouveia, R.S.D.; Lira, G.L.A.; Ramos, T.P.A. \& Medeiros, E.S.F. 2017. Ichthyofauna of the Reserva Biológica Guaribas and surrounding areas, state of Paraíba, Brazil. Check List, 13(5): 581-590.

Gurgel, J.J.S. \& Oliveira, A.G. 1987. Efeitos da introdução de peixes e crustáceos no semi-árido do nordeste brasileiro. Coleção Mossoroense, 453: 7-32.

Kullander, S.0. 1988. A revision of the South American cichlid genus Cichlasoma (Teleostei: (iclidae). Stockhom, Naturistoriska Riksmuseet. 296p.

Langeani, F.; Buckup, P.A.; Malabarba, L.R.; Py-Daniel, L.H.R.; Lucena, C.A.S.; Rosa, R.S.; Zuanon, J.A.S.; Lucena, Z.M.S.; Britto, M.R.; Oyakawa, 0.T. \&
Gomes-Filho, G. 2009. Peixes de Água Doce. In: Rocha, R.M. \& Boeger, W.A.P. (Orgs.). Estado da arte e perspectivas para a zoologia no Brasil. Curitiba, Ed. UFPR, p. 211-230.

Leão, T.C.C.; Almeida, W.R.; Dechoum, M.D.E.S. \& Ziller, S.R. 2011. Espécies exóticas invasoras no Nordeste do Brasil: contextualização, manejo e políticas públicas. Recife, CEPAN e Instituto Hórus. 99p.

Lima, S.M.Q.; Ramos, T.P.A.; da Silva, M.J. \& Rosa, R.S. 2017. Diversity, distribution, and conservation of the Caatinga fishes: advances and challenges. In: Silva, J.M.C.; Leal, I.R. \& Tabarelli, M. (Orgs.). Caatinga the largest tropical dry forest region in South America. Springer. p. 97-131.

Lowe-Mcconnell, R.H. 1999. Estudos ecológicos de comunidades de peixes tropicais. São Paulo, Editora da Universidade de São Paulo. 479p.

Magalhães, A.L.B. \& Jacobi, C.M. 2013. Invasion risks posed by ornamental freshwater fish trade to southeastern Brazilian rivers. Neotropical Ichthyology, 11(2): 433-441.

Malabarba, L.R. \& Reis, R.E. 1987. Manual de técnicas para a preparação de coleções zoológicas. Campinas, Sociedade Brasileira de Zoologia. 14p.

Meneses, L.F.; Pedrosa, E.C.T. \& Furrier, M. 2005. Processos quaternários nos tabuleiros litorâneos da APA Tambaba/PB e possíveis relações com intervenções antrópicas. In: Congresso ABERQUA - Associação Brasileira de Estudos do Quaternário. Anais. Guarapari, ABEQUA. p. 1-6.

Menezes, N.A.; Weitzman, S.H.; Oyakawa, 0.T.; Lima, F.C.T.; Castro, R.M. \& Weitzman, M.J. 2007. Peixes de água doce da Mata Atlântica: lista preliminar das espécies e comentários sobre conservação de peixes de água doce neotropicais. São Paulo, Museu de Zoologia da Universidade de São Paul0. 407p.

Miranda, J.C. 2012. Ameaças aos peixes de riachos da Mata Atlântica. Natureza online, 10(3): 136-139.

Myers, N.; Mittermeier, R.A.; Mittermeier, C.G.; Fonseca, G.A.B. \& Kent, J. 2000. Biodiversity hotspots for conservation priorities. Nature, 403: 853-845.

Nelson, J.S. 2006. Fishes of the World. 4.ed. Hoboken, John Wiley \& Sons. 601p.

Oliveira-Silva, J.T.; Peso-Aguiar, M.C. \& Lopes, P.R. 2008. Ictiofauna das praias de Cabuçu e Berlinque: Uma contribuição ao conhecimento das comunidades de peixes na Baía de Todos os Santos, Bahia, Brasil. Biotemas, 21(4): 105-115.

Oliveira-Silva, L.; Ramos, T.P.A.; Carvalho-Rocha, Y.G.P.; Viana, K.M.P.; Avellar, R.C.; Ramos, R.T.C. 2018. Ichthyofauna of the Mamanguape river basin, Northeastern, Brazil. Biota Neotropica, 18(3).

Osório, F.M.; Godinho, W.0. \& Lotufo, T.M.C. 2011. Ictiofauna associada às raízes de mangue do estuário do Rio Pacoti, CE, Brasil. Biota Neotropica, 11: 1-6.

Oyakawa, 0.T.; Akama, A.; Mautari, K.C. \& Nolasco, J.C. 2006. Peixes de riachos da mata atlântica nas unidades de conservação do vale do rio Ribeira do Iguape no estado de São Paulo. São Paulo, Editora Neotrópica. 201p.

Paiva, A.C.G.; Chaves, P.T.C. \& Araújo, M.E. 2008. Estrutura e organização trófica da ictiofauna de águas rasas em um estuário tropical. Revista Brasileira de Zoologia, 25: 647-661.

Paiva, R.E.C.; Lima, S.M.Q.; Ramos, T.P.A. \& Mendes, L. 2014. Fish fauna of Pratagi River coastal microbasin, extreme north Atlantic Forest, Rio Grande do Norte State, northeastern Brazil. Check List, 10: 968-975.

Pereira, E.H.L.; Lehmann, P. \& Reis, R.E. 2012. A new species of the Neoplecostomine catfish Pareiorhaphis (Siluriformes: Loricariidae) from the Coastal basins of Espírito Santo, Eastern Brazil. Neotropical Ichthyology, 10: 539-546.

de Pinna, M.; Burger, R.; Zanata, A.M. \& 2018. A new species of Copionodon lacking a free orbital rim (Siluriformes: Trichomycteridae). Neotropical Ichthyology, 16: 1/e170146-9.

Ploeg, A. 1991. Revision of the South American cichlid genus Crenicichla Heckel, 1840, with description of fifteen new species and consideration on species groups, phylogeny and biogeography (Pisces, Perciformes, (ichlidae). Amsterdan, Academisch Proefschrift. 153p. 
Ramos, T.P.A. 2012. Ictiofauna de Água Doce da Bacia do Rio Parnaíba. (Doctoral Thesis). João Pessoa. Universidade Federal da Paraíba, 215p.

Ramos, T.P.A.; Maia, J.S.; Costa, S.Y.L.; Silva, M.J.; Avellar, R.C. \& Silva, L.O. 2018. Continental ichthyofauna from the Paraíba do Norte River basin pre-transposition of the São Francisco River, Northeastern Brazil. Biota Neotropica, 18: 1-13.

Ramos, T.P.A.; Ramos, R.T.C.; Rosa, R.S.; Groth, F. \& Beltrão, G.B.M. 2005. Diversidade de peixes (Ictiofauna) da bacia do rio Curimataú, Paraíba. In: Araújo, F.S.; Rodal, M.J.N. \& Barbosa, M.R.V. (Eds.). Análise das variações da biodiversidade do bioma Caatinga: suporte a estratégias regionais de conservação. Brasília, Ministério do Meio Ambiente. p. 291-317.

Reis, R.E.; Kullander, S.0. \& Ferraris Jr., C.J. 2003. Check list of the freshwater of South and Central America. Porto Alegre, Edipucrs. 729p.

Reis-Filho, J.A.; Nunes, J.A.C.C. \& Ferreira, A. 2010. Estuarine ichthyofauna of the Paraguaçu River, Todos os Santos Bay, Bahia, Brazil. Biota Neotropica, 10(4): 301-312.

Reis-Filho, J.A.; Silva, E.M.; Nunes, J.A.C.C. \& Barros, F. 2012. Effects of a red tide on the structure of estuarine fish assemblages in northeastern Brazil. International Review of Hydrobiology, 1-16.

Rodrigues-Filho, C.A.S.; Gurgel-Lourenço, R.C.; Bezerra, L.A.V.; Sousa, W.A.; Garcez, D.S.; Lima, S.M.Q.; Ramos, T.P.A. \& Sánchez-Botero, J.I. 2016. Ichthyofauna of the humid forest enclaves in the tablelands of Ibiapaba and Araripe, Northeastern Brazil. Biota Neotropica, 16(4): e20160273.

Rosa, R.S.; Menezes, N.A.; Britski, H.A.; Costa, W.J.E.M. \& Groth, F. 2003. Diversidade, padrões de distribuição e conservação dos peixes da Caatinga. In: Leal, I.R.; Tabarelli, M. \& Silva, J.M.C. (Eds.). Ecologia e Conservação da Caatinga. Recife, Editora da UFPE. p. 135-180.

Santos, M.C.F. 2000. Diversidade ecológica da ictiofauna acompanhante nas pescarias de camarões em Tamandaré (Pernambuco, Brasil). Boletim técnico-científico do CEPENE-ICMBio, 8: 7-27.
Silva, M.J.; Ramos, T.P.A.; Diniz, V.D.; Ramos, R.T.C. \& Medeiros, E.S.F. 2014. Ichthyofauna of Seridó/Borborema: a semi-arid region of Brazil. Biota Neotropica, 14(3): 1-6.

Soares-Filho, A.A.; Sampaio, C.M.S.; Ferreira, T.D.; Lourenço, J.A.; Sousa, R.A.L. \& Igarashi M.A. 2010. Contribuição ao conhecimento da Ictiofauna estuarina no Estado do Ceará, Brasil. Revista da Gestão Costeira Integrada, 8:1-9.

Sobrinho Jr., A.S. \& Araújo, A.M. 2016. Olhares sobre Tambaba: anteprojeto de alguns mirantes. Revista InterScientia, 3(1): 175-193.

Tabarelli, M.; Pinto, L.P.; Silva, J.M.C.; Hirota, M.M. \& Bedê, L.C. 2005. Desafios e oportunidades para a conservação da biodiversidade na Mata Atlântica brasileira. Megadiversidade, 1(1): 132-138.

Teixeira, F.K.; Ramos, T.P.A.; Paiva, R.E.C.;Távora, M.A.; Lima, S.M.Q. \& Rezende, C.F. 2017. Ichthyofauna of Mundaú river basin, Ceará State, Northeastern Brazil. Biota Neotropica, 17(1): 1-9.

Teixeira, R.L. \& Falcão, G.A.F. 1992. Composição da fauna nectônica do complexo lagunar Mundáu/Manguaba, Maceió, AL. Atlântica, 4: 43-58.

Thayer, G.W.; Colby, D.R. \& Hettler, W.F. 1987. Utilization of the red mangrove prop root habitat by fishes in South Florida. Marine Ecology, Progress Serie, 35: 25-38.

Torelli, J.; Rosa, I.L. \& Watanabe, T. 1997. Ictiofauna do rio Gramame, Paraíba, Brasil. Iheringia, Série Zoological, 82(1): 67-73.

Wang, X.F.; Auler, A.S.; EdwardS, R.L.; Cheng, H.; Cristalli, P.S.; Smart, P.L.; Richards, D.A. \& Shen, C.C. 2004. Wet periods in northeastern Brazil over the past $210 \mathrm{kyr}$ linked to distant climate anomalies. Nature, 432: 740-743.

Zanata, A.M. \& Pitanga, B.R. 2016. A new species of Hypostomus Lacépède, 1803 (Siluriformes: Loricariidae) from rio Itapicuru basin, Bahia State, Brazil. Zootaxa, 4137: 223-232. 


\section{APPENDIX}

\section{Identification key to species from the Tambaba APA, Graú, Mucatú, and Bucatú river basins, Caboclo River sub-basin and Gurugi River basin in Paraíba State, Brazil}

1 .

2.

2.

3.

$3^{\prime}$.

4.

$4^{\prime}$.

5.

$5^{\prime}$

Gill slits ventrally located, dorsal and anal fins very reduced or absent.

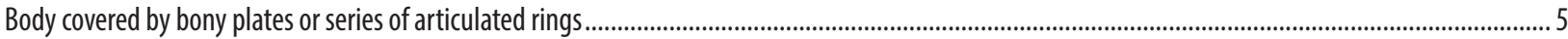

Body covered by typical scales.

Body fusiform and covered by bony plates

Megalechis thoracata

Body tube-like and covered by series of articulated rings

Microphis brachyurus

27-28 rays in dorsal fin, 27-34 rings in caudal region

Syngnathus pelagicus

Fins with soft rays only.....

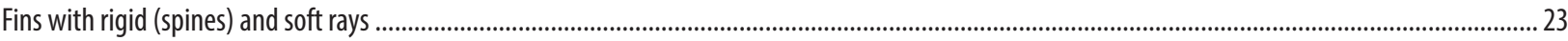

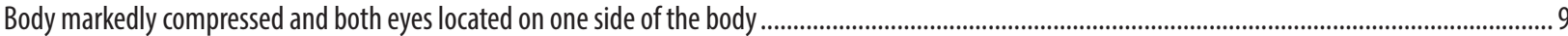

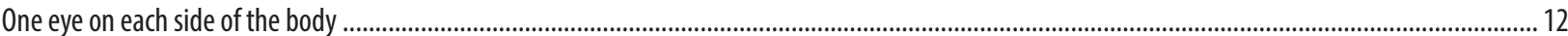

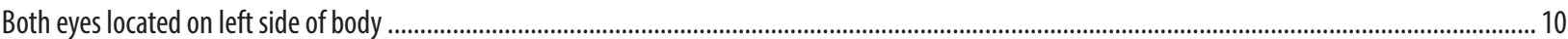

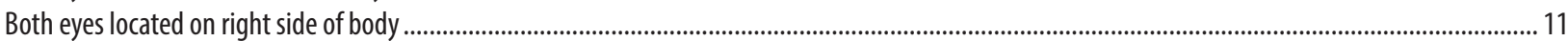

First dorsal-fin ray inserted above and adjacent to the anterior nostril on the blind side of the body

. Citharichthys sp.

First dorsal-fin ray inserted above and remote to the posterior nostril or equidistant to the two nostrils

Citharichthys spilopterus

Body brown and 10 to 11 transversal lines black in color present....

Trinectes paulistanus

Body brown, transversal lines absent, light markings rounded, forming a mosaic

Trinectes inscriptus

Dorsal and pelvic fins absent, anal fin markedly elongate with more than 140 rays.

Gymnotus carapo

Dorsal and pelvic fins present, anal fin markedly small with less than 140 rays.

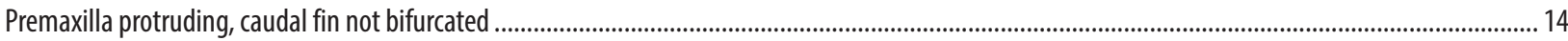

Premaxilla non-protruding, caudal fin bifurcated or not bifurcated ........................................................................................................................ 16

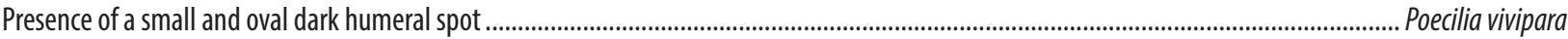

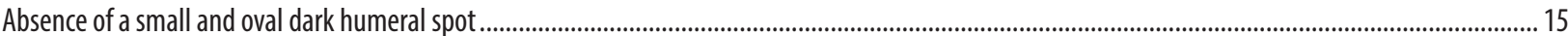

Lateral region of body with many colorful spots.........................................................................................................................Poecilia reticulata (male)

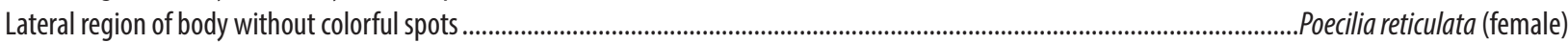

Lateral line and adipose fin absent..

Lycengraulis grossidens

Lateral line and adipose fin presents.

Adipose fin absent and caudal fin rounded

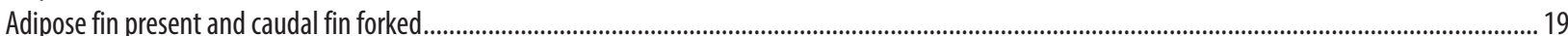

Maxilla with conical teeth only.

Hoplias malabaricus

Maxilla with conical and canine teeth

Abdomen compressed, forming a keel prior to the pelvic fins

Erythrinus erythrinus

Abdomen rounded not forming a keel prior to the pelvic fins.

Metynnis lippincottianus

Premaxilla with a single series of teeth

Compsura heterura

Premaxilla with two series of teeth

Lateral line complete.

Astyanax bimaculatus

Lateral line incomplete.

Blackish marking on the caudal peduncle or under the median caudal rays present, dorsal and hyaline fins with black vertical bar absent

Cheirodon jaguaribensis

Blackish marking on the caudal peduncle absent, dorsal and anal fins with black vertical bar presents.

Hemigrammus unilineatus

Pelvic fins absent

Pelvic fins present...

Dermal appendix present dorsal and laterally on body

Sphoeroides spengleri

Dermal appendix absent

Sphoeroides testudineus

Pelvic fins fused, forming a suction disk

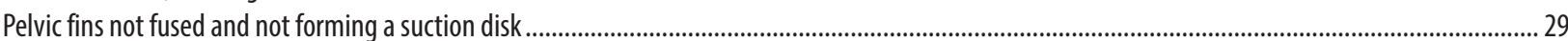

Eight to nine rays in anal fin

Bathygobius soporator

More than 10 rays in anal fin

Eleven rays in anal fin 
28. Dorsal fin with six spines and 14 rays

28. Dorsal fin with six spines and 12 rays, anal fin with 13 rays.

Ctenogobius boleosoma

29.

Lateral line absent Evorthodus lyricus

29 .

Lateral line present.

... 30

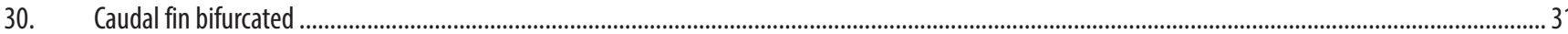

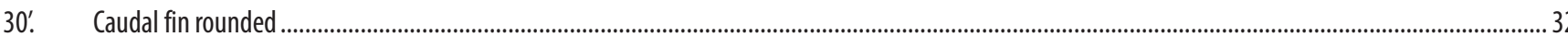

31. Silver bar present horizontally, one spine and 17-19 rays in anal fin ...........................................................................................Atherinella brasiliensis

31. $\quad$ Silver horizontal bar absent, 2-3 spines and nine or 10 rays in anal fin ....................................................................................................... Mugil curema

32. 29-31 rows of longitudinal scales on body ................................................................................................................................... Dormitator maculatus

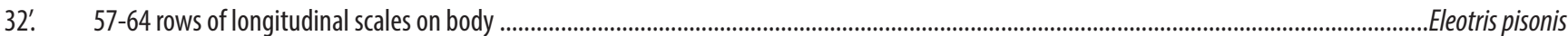

33. Lateral line discontinuous with upper (anterior) and lower (posterior) branches ..................................................................................................... 34

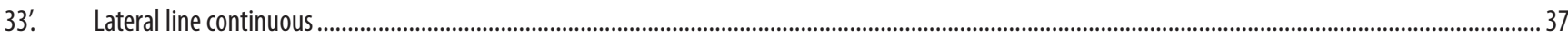

34. Dorsal fin incised between anterior and posterior portions ..................................................................................................................chla monoculus

34. $\quad$ Dorsal fin without a fork between anterior and posterior portions ............................................................................................................................... 35

35. Upper branch of first gill slit with prominent lobe, black vertical bar over the eye present, reaching the corner of preopercle............. Geophagus brasiliensis

35'. Upper branch of first gill slit without prominent lobe, black vertical bar over the eye absent.......................................................................................... 36

36. Body elongated and fusiform, posterior margin of preopercle serrated ............................................................................................ Crenicichla brasiliensis

36. Body tall and oval, posterior margin of preopercle straight .................................................................................................................... Cichlasoma orientale

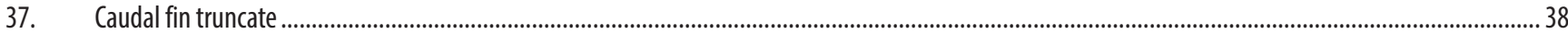

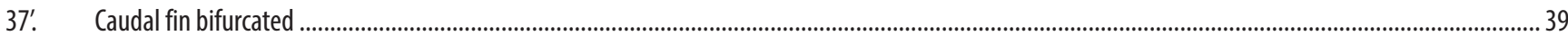

38. Six scales between the dorsal fin origin and the lateral line ...................................................

38. Nine to 10 scales between the dorsal fin origin and the lateral line......................................................................................................... Lutjanus jocu

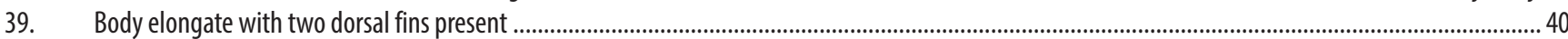

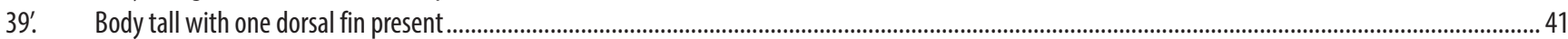

40. Mouth with large canine teeth, two spines and 8-9 rays in anal fin............................................................................................... Sphyraena barracuda

40'. Mouth with villous teeth, three spines and 5-6 rays in anal fin ......................................................................................................entropomus undecimalis

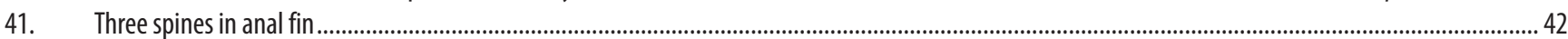

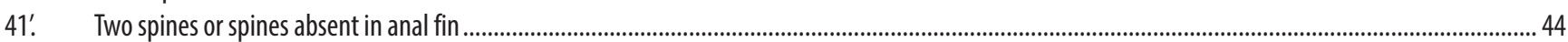

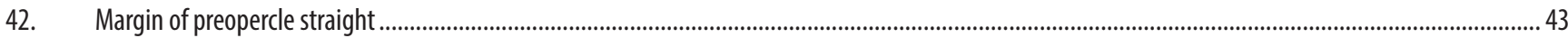

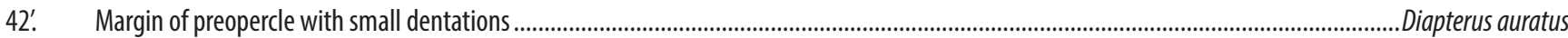

43. Premaxilla furrow discontinuous anteriorly by scales ......................................................................................................................Eucinostomus gula

43.' Premaxilla furrow continuous not interrupted anteriorly by scales............................................................................................... Eucinostomus argenteus

44. Two spines in anal fin, dorsal-fin rays without scales................................................................................................................. Abudefduf saxatilis

44'. Anal fin without spines, dorsal-fin rays completely covered of scales ............................................................................................ Haemulon aurolineatum 